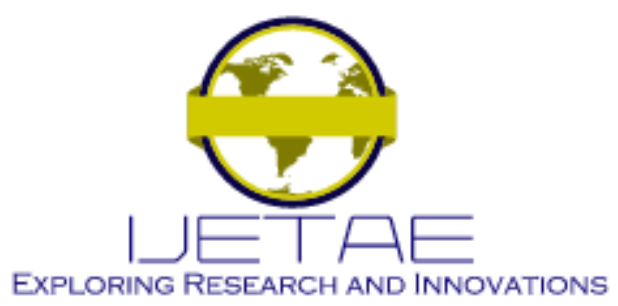

International Journal of Emerging Technology and Advanced Engineering

Website: www.ijetae.com (E-ISSN 2250-2459, Scopus Indexed, ISO 9001:2008 Certified Journal, Volume 11, Issue 11, November 2021)

Manuscript Received: 08 October 2021, Received in Revised form: 19 October 2021, Accepted: 03 November 2021

DOI: 10.46338/ijetae1121_02

\title{
Improvement of Information Technology and Its Impact on Information Security
}

\author{
Vadim Avdeevich Avdeev ${ }^{1}$, Olga Anatolievna Avdeeva ${ }^{2}$, Vera Vladimirovna Smirnova ${ }^{3}$, \\ Ilya Mihajlovich Rassolov ${ }^{4}$, Maria Alekseevna Khvatova ${ }^{5}$

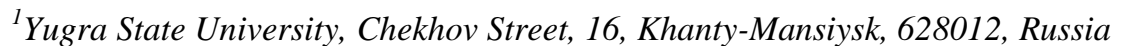 \\ ${ }^{2}$ East-Siberian Institute of the Ministry of Internal Affairs of the Russia, Lermontov Str. 110, Irkutsk Region, Irkutsk, \\ 664028, Russia \\ ${ }^{3}$ Russian University of Transport, Obraztsova Str., 9, building 9, Moscow, 127994, Russia \\ ${ }^{4}$ Kutafin Moscow State Law University (MSAL), Sadovaya-Kudrinsky Str. 9, Moscow, 125993, Russia \\ ${ }^{5}$ Bauman Moscow State Technical University, 2nd Bauman Str., 5, building 1 Moscow, 105005, Russia
}

\begin{abstract}
The article reveals the problems of information security in modern conditions with the globalization of international life, changing polycentric relations, taking into account the high rates of development in technical and information resources. The special importance of ensuring information security as an object of legal protection protected by international and national law is noted. The issues of eliminating conflicts in the norms of international law, preventing the possibility of their spreading to the territory of individual sovereign states, are being addressed. The correlation between the norms of international and national law emphasizes the expediency of improvement and adoption of new normative legal acts of universal and regional significance which can be used by member states when innovating national criminal and other sectoral legislation. It is a priority to improve international and national legal policy for the modernization of national legal systems for the prevention and combating of cybercrime. An effective mechanism of legal regulation for the objects to be legally protected is of fundamental importance for ensuring information security. Particular attention is focused on solving the issues of detection, disclosure and accurate legal evaluation of crimes and offences committed in cyberspace. The importance of the international community to establish universal standards to ensure information security is emphasized.
\end{abstract}

Keywords-international law, national law, legal policy, information security, information technology, technical and information resources, cyberspace, cybercrime.

\section{INTRODUCTION}

The modern stage of international and state-legal development is characterized by improvements in information technologies which is reflected in their impact on ensuring information security at both the interstate and national levels. It is quite understandable that the international community is concerned about the problems of information security, given the steady growth of crimes and other offenses committed with the use of telecommunications and other information technologies [1].

The maintenance of interstate ties and relations dictates the need to develop and adopt an international normative legal act of a universal nature guaranteeing security in cyberspace. This international legal framework would ensure that states apply the same principles in organizing activities to ensure security in cyberspace.

The central problem of the current study is ensuring national security in the context of globalization predetermines the need to establish strategic directions that contribute to the protection of legitimate rights, freedoms and interests of individuals, society and the state from internal and external negative impacts. The high rate of development in technical and information resources actualizes the issues of optimization in the field of information security [2]. Increasing globalization of international life causes intensification of efforts in the international community to legislate universal standards ensuring information security. 


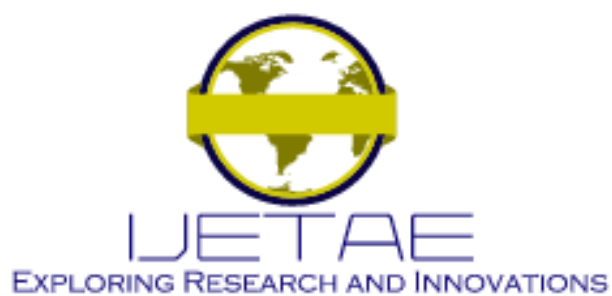

International Journal of Emerging Technology and Advanced Engineering

Website: www.ijetae.com (E-ISSN 2250-2459, Scopus Indexed, ISO 9001:2008 Certified Journal, Volume 11, Issue 11, November 2021)

The norms of national legislation that take into account the peculiarities of socio-economic and political-legal nature in the modern conditions of development in the national statehood deserve consistent modification. The existing realities of interstate life allow us to note the significant importance of legal policy, the guidance of which allows us to outline the main aspects of legal protection from encroachments on the most significant interests in the field of information security for citizens, society and the state.

\section{LITERATURE REVIEW}

Adoption of international documents ensuring transparency of public administration is of fundamental importance. An example is the Convention adopted at the Stockholm Conference on 14.07.1967. According to this Convention, the member-states are obliged to provide mutual information disclosing the national legislation, judicial system, procedures in commercial and civil activities.

In the field of access to justice the Committee of Ministers of the Council of Europe member-states has adopted Recommendation № R (81) 7 of 14.05.1987, addressed to the respective governments of the memberstates on the necessity to take and strengthen measures for consistent realization of the principles to facilitate access to justice for citizens and informing them on the means to protect their rights in court. Tax, social, administrative, commercial and civil litigation is subject to acceleration, simplification and cheapening.

The 1989 European Convention on Transfrontier Television regulates the key principles of regulation for transfrontier television, based on the existing Recommendation on Audiovisual Media which includes rules oriented to the harmonious development of transfrontier television programs and the protection of human rights. States parties are required to guarantee freedom of information and expression, to accept and avoid restricting the retransmission within their territory of programmes covered by the Convention.

Directive 89/552/EEC of 03.10.1989, which aims to authorize the free circulation of audiovisual information in the form of television and radio broadcasting, is worth noting in this regard. The document pays special attention to the coordination of national rules excluding the possibility of imposing restrictions on the freedom for broadcasting.
The main principle of the Directive is the freedom for broadcasting, the management of which ensures at the same time the protection of health, consumer rights and etc. Restriction of broadcasting is provided for example in cases of audiovisual information containing violence or pornography capable of causing significant harm to the moral, spiritual or physical development of minors. Participating States undertake to ensure that there is no incitement to national, religious, sexual or racial hatred in television broadcasts.

The 1992 Convention of the International Telecommunication Union is of certain interest, whose radio regulations establish the provision of certain frequencies required for broadcasting via satellites for information, culture, science and education purposes. The said Convention enshrines the key principles of information dissemination via satellites.

Recommendation № R (1994) 13 of the Committee of Ministers to member states of the Council of Europe "On measures to ensure media transparency" prescribes that the public may have unbiased and fair access to basic information on the media. In the Annex to this Recommendation the principles of the transparency regime of media disseminators are to be formalized.

The Recommendation № 11 of 11.09 .1995 of the Committee of Ministers to the member states of the Council of Europe is of fundamental importance for the presentation, processing, selection and archiving of court decisions in retrieval systems. The said Recommendation notes the necessity of maintaining a data bank, new optical and magnetic information carriers in automated retrieval systems for information on jurisprudence.

The 1995 Johannesburg Principles regulate the establishment of access to information, freedom of expression, national security as a guiding framework for access to government information, promoting the recognition of limitations on freedom of information and expression for national security purposes.

Directive 1999/93/EC on a Legal Framework for the Regulation of Electronic Signatures in the Community, which requires that electronic information concerning court proceedings be made available to the public, is subject to signature. Directive 2000/31/EC of the European Parliament and of the European Union regulates specific legal aspects of providing services to the information community, including those concerning certain commercial transactions on the Internet. 


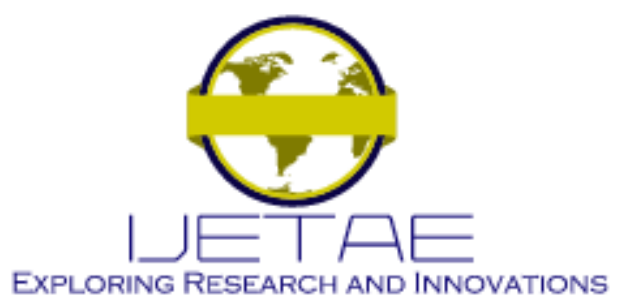

International Journal of Emerging Technology and Advanced Engineering

Website: www.ijetae.com (E-ISSN 2250-2459, Scopus Indexed, ISO 9001:2008 Certified Journal, Volume 11, Issue 11, November 2021)

Recommendation Rec (2001) 2 of the Committee of Ministers to member states of the Council of Europe notes the role of electronic technologies in improving legal information systems, justice systems, ensuring security of access to data, using electronic signatures to guarantee the integrity of data in the system.

The regulation of relations in the information environment is promoted by the Recommendation of the Council of Europe of 28.02.2001. This Recommendation regulates the solution of questions relating to states' obligation to provide access to electronic registers in the legal sphere, to legal information in electronic form, to ensure the automation of judicial technologies. The Committee of Ministers' Recommendation Rec (2002) 2 states that the main principle of access to official documents for member states is to guarantee everyone the right of access to the requested information held by official authorities.

Particularly noteworthy is the 2001 Convention on Cybercrime, which requires parties to provide the greatest measure of legal assistance for investigations and prosecutions of criminal offences involving computer data and systems.

Current principles of freedom to express opinions and disseminate information on the global networks are regulated by the 2003 Declaration on Freedom of Internet Communication, the 2005 Declaration of the Committee of Ministers of the Council of Europe on Freedom of Expression and the Media in the Context of the Fight against Terrorism, the 2005 Council of Europe Parliamentary Assembly Recommendation № 1706 "Mass Media and Terrorism".

The outcome documents of the World Summit on the Information Society, adopted in 2005 in Tunis, are considered significant. The Tunis Agenda and Commitment recognizes that information and telecommunications technology is valued as an effective tool to promote stability, security, peace, social cohesion, democracy and good governance. The rule of law at the international, national and regional levels is emphasized. Close attention is paid to the importance of preventing the abuse of information technologies and resources for criminal purposes.

On November 23, 2005 the UN General Assembly adopted the Convention on the Use of Electronic Communications in International Contracts.
The Convention is aimed at increasing the efficiency of commercial activities and has been open for signing since January 16, 2006. The Convention is aimed at providing countries with different socio-economic and legal systems with equal access to modern trade channels. The key objective is to remove possible legal obstacles for the development of electronic commerce, ensuring the free movement of persons, capital and goods, the effective functioning of the internal market of the European Union. The Directive regulates the framework regulation of electronic signature key certificate services and their application.

\section{METHODS}

The methodology of cyber security research at the international and national levels involves a combination of methods, tools and techniques of scientific research.

First of all, this research is aimed at studying the real state of information security. In this regard, statistical data demonstrating the state of security threats in the current conditions of information and telecommunications technologies development have been thoroughly studied [3].

The method of comparative-legal analysis was actively applied, with the help of which the most criminogenic areas in the field of information and telecommunication space were identified. The analysis of implemented measures to counteract threats to cybersecurity, actively developing at the international level since the early 80 s of XX century, was given.

The formal legal method was used as one of the basic research methods. On the basis of this method the analysis of legal acts was carried out, which allows to conclude that the formation and development of the legal basis in the unified information and telecommunication space is associated with the need to make additions to the content of international normative legal acts. It seems expedient to fix the principles of implementation in information and telecommunications technologies, to establish balance and consistency between national legal norms on the basis of universally recognized principles and norms of international law.

To solve the problem indicated in the introduction key technological advances in the protection of modern cyber systems must be evaluated. 


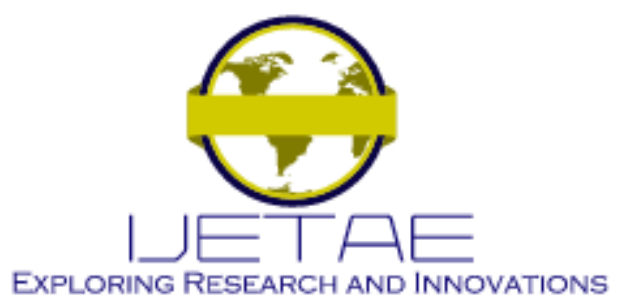

International Journal of Emerging Technology and Advanced Engineering

Website: www.ijetae.com (E-ISSN 2250-2459, Scopus Indexed, ISO 9001:2008 Certified Journal, Volume 11, Issue 11, November 2021)

It is necessary to understand the relevance of the security problem in the digital world order, which determines the awareness of the urgency for developing and implementing comprehensive measures to counter cybercrime. A pragmatic approach is recognized, requiring a scientific justification of the likely global threats for the foreseeable future. As a consequence, in order to ensure cybersecurity, tasks for the development and implementation of effective means of prediction, prevention and counteraction should be outlined.

\section{RESUlTS}

It is worth noting that nowadays the problem of legal provision for information security requires new solutions due to the emergence in new challenges and risks. The reason is the rapid development of information and communication technologies, the use of which outside the legal field leads to adverse consequences both for the state and businesses in the various forms of ownership and the welfare of the population associated with the protection of personal and property interests. This trend of improving threats to cybersecurity has led to an increase in crime rates and the formation of new types for encroachments in the digital information format $[4,5]$.

The key areas of information security in international practice should be considered:

1) Rationing of computer security based on criteria for evaluating reliable systems and information technology security;

2) Standardization of the processes for education and development of secure information systems.

The problem of security in cyberspace involves the protection of individuals in the automated processing of personal data, the objectives of which are:

1) Legal protection of the individual in the automated processing of personal information;

2) Strengthening the protection of personal data.

It is required to consolidate the requirements for personal data, defining the principles of their fair, lawful collection and processing. It is necessary to ensure personal security against abuses in the collection and use of personal data. At the same time, cross-border flow of personal data is subject to legal regulation [6].

It is relevant to distinguish the following levels of security: a) guaranteed protection; b) full access satisfaction; c) selective access control; d) minimum security.
The main components of security should be considered: security classes; overall security assessment; security assurance; a set of security features; security threat; product security; system security; information security.

In view of the growing threats to cybersecurity, it is advisable to develop a convention on cooperation in combating cybercrime within the framework of the United Nations. A universal approach to the nature of this project is required. It will unite the global community in the fight against cybercrime [7].

The project must take into account the opinions of foreign partners and heads of special services. Proceeding from the aim of the project, which is to consolidate international resources for the prevention of crimes and illegal acts in the sphere of information and communication technologies, the list of illegal infringements should include: 1) crimes related to information protected by national law; 2) illegal access to information; 3) development and use of malware and spam;4) crimes related to child pornography; 5) violation of copyrights.

Given the European criteria, the elements of detailing information security are: description of security mechanisms; availability of information; information integrity; confidentiality of information; specification of security functions; functions and objectives of information security.

Of particular importance is the improvement of the information security mechanism in terms of procedures for using personal data by the police. In order to improve the effectiveness of measures taken by the international community in the field of information security, it is worth emphasizing the consolidation of resources to combat crimes against the integrity, confidentiality, availability of computer systems and data. Issues of access and obtaining by investigative authorities through the computer system to computer data stored in the territory of another Party are a problem [8].

Attention should be paid to the declaration of principles on information society issues and the need to build an information society, increasing security and trust, using information technology.

The construction of an open information society should be recognized as basic principles. The communication and information infrastructure should be considered as the basis for building an information society [9]. 


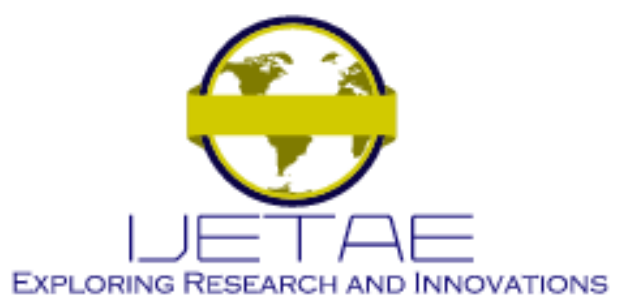

International Journal of Emerging Technology and Advanced Engineering

Website: www.ijetae.com (E-ISSN 2250-2459, Scopus Indexed, ISO 9001:2008 Certified Journal, Volume 11, Issue 11, November 2021)

As a suggestion on the results of the study, it is worth mentioning the necessity of introducing additional guarantees for everyone to have access to requested official documents held by public authorities. At the same time, this approach should be reflected in national legal systems.

As new threats to cybersecurity were identified as: unauthorized electronic access to information; impact on information and its interception; creation, distribution and use of malicious software; illegal trafficking of devices, theft through digital technology; spam distribution and etc.

The development of rules for responsible behavior in the digital realm has been identified as a key area of cybersecurity in today's information space. Close attention is focused on the development and implementation by participating countries of measures to counteract hacking as one of the widespread types in cybercrime [10].

The project "On cooperation in counteracting information crime" must contain measures promoting technical legal interaction. Particular attention should be paid to joint investigations, collection of traffic parameters and transfer of convicts. Establishment of a 24/7 contact center is of practical importance. It is worth mentioning that the distinction of these recommendations is: 1) universalization of international law under the aegis of the $\mathrm{UN}$; 2) eliminating the possibility of introducing special services into the computer systems in foreign countries; 3 ) creating a mechanism to respect the sovereignty of states.

\section{DISCUSSION}

The following are recognized as key requirements for the legislation of member states: 1) voluntary accreditation of providers of services provided; 2) guarantees of free circulation; 3) transnational use; 4) guarantees to protect the interests of individuals; 5) adoption by member states of legal and regulatory acts in accordance with the Directive (articles 3, 4, 8, 15).

The UNGA resolution 62/17 of 05.12.2007 underlines the necessity for the participating countries to ensure multilateral consideration of existing potential threats in the field of information security and possible measures to limit and neutralize them.

Of particular interest in the modern period is the Deauville Declaration of 2011, which includes a section devoted to the Internet. According to this Declaration, provisions concerning the principles of Internet functioning are to be consolidated, including respect, freedom of privacy, intellectual property, protection from crime, cyber security and etc.
International exhibition and conference on cybersecurity held in Dubai (UAE) on 31.05-02.06.2021, where new developments in the field of computer security, including protection of intellectual property, data loss, e-mail and etc. were presented, deserves a certain attention. The developed types of security on the networks, mobile applications and devices, business transactions are of practical importance. Significant are presented antivirus programs, technologies of information protection in "cloud" storages, information security Internet of things, cryptographic protection of information, technologies of digital forensics, technologies of identification and management of access to information.

Indicative is the adoption of a number for peace and security within the UN General Assembly and the OSCE in the field of peace and security, which are the most significant legal acts aimed at intensifying the formation of post-industrial areas for the development in spiritual, sociopolitical and economic spheres of society.

In the framework of the UN General Assembly in 2017, the idea of uniting the efforts of states to counter cybercrime was actively promulgated. For this purpose, the issue of adopting a draft convention on combating cybercrime of a universal nature was brought up for discussion.

The problem of overcoming the threat to cybersecurity in the conditions of modern globalization processes predetermined an increased interest in the creation of a mechanism that would prevent the use of information and communication technologies as a means of influence, causing economic harm, propaganda of terrorist and extremist ideology. It is noteworthy that proposals were made to form a Russian-American cybersecurity group.

During the meeting of the UN General Assembly on November 09, 2018, a draft resolution revealing the feasibility for creating a code of responsible behavior of states on the Internet was proposed. According to this draft, the new emerging opportunities in the field of information and communication technologies are inevitably reflected in the growth of relevant types of crime. As a consequence, at the international level is actualized the need: 1) to establish within the UN General Assembly an open-ended working group on international information security; 2) to regulate the list of rules for responsible behavior of countries in the information space. 


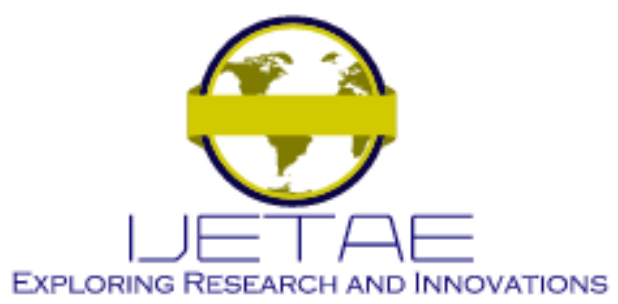

International Journal of Emerging Technology and Advanced Engineering

Website: www.ijetae.com (E-ISSN 2250-2459, Scopus Indexed, ISO 9001:2008 Certified Journal, Volume 11, Issue 11, November 2021)

As a follow-up to this project, a draft resolution on combating the use of information and communication technologies for criminal purposes was proposed for consideration by the UN General Assembly on November 13, 2018. The project emphasized the growing trend of increasing number of crimes in the digital world and their negative impact, determining the critical state of the infrastructure among countries. In this regard, suggestions were made about the need for the international community to detail the rules for the conduct of States aimed at resolving issues related to the exchange of information.

The issue of international cooperation to effectively counter cyber threats and cyber attacks was again subject to discussion on May 20, 2019 at the 28th session of the UN Commission on Crime Prevention and Criminal Justice. Underscoring the relevance of the problem, the international community noted the urgent need to improve the legal framework in the field of combating cybercrime.

Taking into account the expediency of a comprehensive approach to the analysis for the global situation in the field of cybercrime, the special importance in holding a discussion with the participation of representatives from the business community and academic circles and finding ways to solve problems in the field of countering the criminal use of information and communication technologies was emphasized $[11,12,13]$.

It is noteworthy that within the framework of the Second International Congress on Cyber Security, held on June 2021, 2019 in Moscow, the main global cyberthreats, as well as methods, ways and means of counteraction were subject to expert discussion. The main focus for the forum was the development of an international strategy for cooperation between states and law enforcement agencies in the field of countering cybercrime.

\section{ConClusions}

To summarize, it should be concluded that it is still relevant to adopt a universal international normative legal act to guide the legal policy of states on the legal regulation of key areas of information security, taking into account the inherent national characteristics of each state. Among the strategic areas for legal regulation is the need to improve the legal framework in the light to the renewed cyberthreats in the context of the development of new digital technologies. It is necessary to form a legal mechanism to improve the quality and stability of the elements for public administration in relation to the financial system.
Adoption of appropriate legal measures becomes relevant to strengthen public-private partnerships, creation and successful implementation of practice-oriented programs that ensure a high level of protection for credit institutions. In modern conditions it is advisable to form a cyber culture and improve literacy of the population through the relevant informational and educational activities. Law enforcement bodies should be more active in detection, disclosure and investigation of computer crimes which acquire transborder character in modern conditions.

The steady growth in the number of offences under chapter 28 of the Criminal Code of the Russian Federation means that problems associated with detection, disclosure, proof and identification of the perpetrator, including an accurate legal assessment of the committed act, must be resolved.

The formulated provisions in the field of improving the quality for legal provision of information security at the national level should be supported by the adoption of legal measures to build a system for information security at the interstate and international levels through the development of mutually beneficial cooperation between states. It should be taken into account that improving the effectiveness of measures to ensure international cybersecurity determines the uniform approach to the qualification of unlawful acts committed in the field of high technology.

\section{Acknowledgments}

The article was prepared in the course of the Scientific school "Scientific support of the effectiveness of the implementation of modern criminal law policy (taking into account the criminological characteristics of the northern region)" of research of the federal state budgetary educational institution of higher education "Ugra State University" (Khanty-Mansiysk, Autonomous OkrugYugra).

\section{REFERENCES}

[1] Afanasyeva, V.I. 2006. The legal nature of the subjective right to an invention. Interuniversity collection of scientific papers. 3, 30-35.

[2] Avdeev, V.A., Avdeeva, E.V. 2019. Social Technologies of Receiving New Information. International Journal of Engineering and Advanced Technology (IJCIET). 8(6), 5279-5282.

[3] Levina, E.Y., Masalimova, A.R., Kryukova, N.I., Renglikh, K.A., Shagieva, R.V. 2017. Structure and content of e-learning information environment based on geo-information technologies. Eurasia Journal of Mathematics, Science and Technology Education. 13(8), 50195031. http://doi.org/10.12973/eurasia.2017.00974a 


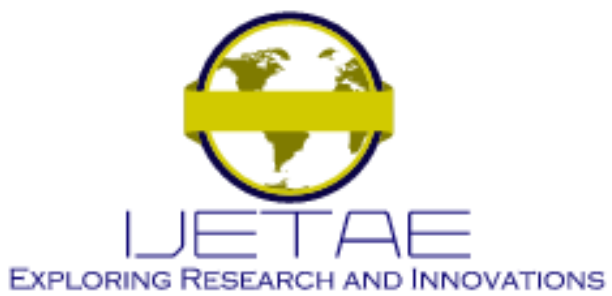

International Journal of Emerging Technology and Advanced Engineering

Website: www.ijetae.com (E-ISSN 2250-2459, Scopus Indexed, ISO 9001:2008 Certified Journal, Volume 11, Issue 11, November 2021)

[4] Khvatova, M.A., Magomedov, R.M., Magomedrasulov, M.N., Lisitzina, T.B., Marchenko, A.A., Evdokimova, E.V., Saranchuk, Y.M., Shagieva, R.V. 2019. Overcoming Dangers Of Modern Techno-Sphere As Priority Strategy For Biosphere And Man Sustainable Development. Ekoloji. 107, 4949-4954, Article No: e107561.

[5] Ovchinsky, V.S. 2004. International legal framework for combating illegal migration and trafficking in persons. INFRA-M, 103-146.

[6] Avdeev, V.A., Avdeeva, O.A., Gribunov, O.P., Sergevnin, V.A . 2016. Punishment in the system of criminal law measures of counteracting corruption: Interaction of legal systems in the conditions of international life's globalization. Criminology Journal of Baikal National University of Economics and Law. 10(2), 301312.

[7] Kartashkin, V.A., Lukasheva, E.A. 2002. International instruments on human rights. Norma, INFRA-M, $944 \mathrm{p}$.

[8] Pravkin, S.A., Smirnova, V.V., Shagieva, R.V., Khvatova, M.A. 2020. The Significance Of The Principle Of Legality In The System Of Legitimacy Of N.M. Karamzin. Bylye Gody. 55(1), 67-76.
[9] Avdeev, V.A., Avdeeva, O.A., Mayorova, E.I., Melnikova Y.V., Filippova A.V. 2020. The Legal Framework Ensuring Protection Of The Natural Environment. Journal of Critical Reviews. XI, 7(13), 340-344.

[10] Ananidze, F.R. 2006. Some problems of defining the concept of «indigenous people». Lawyer- International. 2

[11] Avdeev, V.A., Avdeeva, O.A. 2014. Main directions of national criminal and legal policy in the sphere of counteraction of crime realization: federal and regional principles comparative analysis. Criminology Journal of Baikal National University of Economics and Law, 2, 46-62

[12] Avdeev, V.A., Avdeeva, O.A. 2014. Criminal legal concept of the Russian Federation: main directions of criminal law improvement and crime counteraction measures optimization. Criminology Journal of Baikal National University of Economics and Law, 1, 1224.

[13] Eremin, S.G., Lukichev, K.E., Belyaev, A.M., Romashkova, I.I., Khvatova, M.A. 2020. Mirror Microsoft Ml Network For Recognition And Organization Of Objects In Law. International Journal of Advanced Trends in Computer Science and Engineering. 9(4), 327, 6429-6432. 